\title{
Floristic characteristics of Mt. Nemrut National Park and its surroundings (Adıyaman)
}

\author{
Basri MUTLU(i \\ Hakkari Forest Directory Hakkari-Turkey \\ Corresponding author: basrimutlu@ogm.gov.tr
}

\begin{abstract}
Floristic characteristics of Mt. Nemrut National Park and its surroundings and the list of vascular plant species growing there are documented. Mt. Nemrut National Park is situated on the Southeast Taurus mountain range and is in the Iran-Turanian phytogeographical region. The research was carried out between 2010 and 2013. Two thousand five hundred plant specimens were collected from the area. At the end of the study, 777 vascular plant species and 403 genera belonging to 88 families were identified: 118 taxa $(15,19 \%)$ are endemic to Turkey. The phytogeographic elements are represented in the study area as follows: Irano-Turanian 271 (34,9\%), Mediterranean 52 (6,7\%), E. Mediterranenen 44 (5,7\%), Euro-Siberian 22 (2,8\%), Euxin $2(0,3 \%)$ and Unknown $386(49,7 \%)$.
\end{abstract}

Key words: Adiyaman, Flora, Mt. Nemrut National Park, Vascular plants.

\section{Özet}

$\mathrm{Bu}$ araştırmada, Nemrut dağı milli parkı ve yakın çevresinin floristik özellikleri ve burada yetiştiği saptanan damarlı bitki taksonlarının listesi verilmiştir. Nemrut Dağı Milli Parkı, Güneydoğu Toros dağ silsilesi üzerinde yer almakta ve İran-Turan bitkicoğrafyası bölgesinde bulunmaktadır. Araştırma 2010-2013 yılları arasında yapılmıştır. Araştırma alanında 2500 bitki örneği toplanmıştır. Araştırma sonucu 88 familya'ya ait 403 cins'e bağlı 777 vasküler bitki türü saptanmıştır. Taksonlardan 118'i $(\% 15,19)$ Türkiye için endemiktir. Araştırma alanındaki fitocoğrafik elementlerin dağılımı ise şöyledir: Iran-Turan 271 (\%34,9), Akdeniz 52 (\%6,7), Doğu Akdeniz 44 $(\% 5,7)$, Avrupa-Sibirya $22(\% 2,8)$, Öksin $2(\% 0,3)$ ve Flora bölgesi bilinmeyen $386(\% 49,7)$ 'dir.

Anahtar sözcükler: Adıyaman, Flora, Nemrut Dağı Milli Parkı, Vasküler bitkiler.

\section{Introduction}

Protected areas, which also contribute to economic and social development through the protection of natural-cultural resource values, are an indispensable tool of conservation and resource utilization policies. The primary function of conservation is to ensure the continuity of biodiversity in protected areas, including national parks which are the most important centers where sustainable development can take place. However, the biggest problem encountered in ecological planning studies in our country is the lack of sufficient biological and ecological inventories. Therefore, it is of great importance that the accurate and precise inventory of the biological asset is presented in detail.

In the inventory studies, it provides detailed information about the structure and functioning of the landscape since plants find everywhere at the same time as well as it creats different parts of the landscape visually and it is the great importance for other living on presence of vegetation organisms and it is related to habitats and environmental factors. Therefore, priority is given to vegetation analysis 
which is a basic step for (ecological) planning while setting out the management plans, conservation objectives and strategies of protected areas. However, it is necessary to know the flora to successfully be investigated vegetation.

Although flora studies have been carried out in many areas in our country, a limited number of studies have been conducted in and around Mount Nemrut and 80 taxa have been recorded from this area in Flora of Turkey (Davis, 1965-1988).

A systematic list of 175 taxa was presented by Uzun et al (2001) including Davis (1965-1988)'s records compiled flora of the National Park. Of the taxa in this list, 95 taxa were stated as new records during field observations and endemic species were given together with their localities. Tel (2001) identified 250 vascular plant species and 149 genera belonging to 44 families. Çakan et al. (2004) and Tuluhan et al. (2004) stated to be represent by 513 taxa in the area but they did not present a systematic list.

In spite of all these new studies, since the flora and vegetation structure of the area, which was declared a national park in 1989, could not be fully revealed, the targeted conservation strategies could not be reached. It is essential to determine the conservation priorities immediately by investigatig the endemic, rare and endangered species that have indicative in detail to create sustainable conservation strategies at the national park.

In order to reach the conservation strategies targeted at the LTDP (long-term development plan) in the Nemrut Mountain National Park, the floristic inventory was the initial stage of the work due to the most important ecological resource revealing the ecological characteristics of national park and included the distribution areas of taxa in this inventory, whether they are endemic or not and the hazard categories.

The floristic inventory at the end of study is a reference for researchers in ecological studies on Mount Nemrut and its surroundings on the Southeastern Taurus Mountains that is one of the many areas that Davis described as floristically middle, little or no work and suggested that studies should be conducted at the local level and in detail. As well as it should also be considered as a contribution to the flora studies of our country.

\section{Materials and methods}

\section{Characteristics of the work area}

The study area is Nemrut Mount National Park and its geograpic location, geo-morphologic, geologic, soil, climate, hydrologic and vegetation characteristics are given below.

\section{Geographical situation}

Nemrut Mount National Park is situated on a strategic area that is $37^{\circ} 51^{\prime} 30^{\prime \prime} 38^{\circ} 00^{\prime} 30^{\prime \prime}$ north latitude $38^{\circ} 34^{\prime} 30^{\prime \prime}-38^{\circ} 48^{\prime} 30^{\prime \prime}$ east longitude, which provides access to the Euphrates and Taurus passages from Syria and Upper Mesopotamia to the Anatolian plateau in northern end of the area of called Fertile Crescent between the Euphrates, Tigris and the Nile rivers. The study area that is the national park area (13850 ha) and its surroundings is almost 20,000 hectares (Figure 1).

\section{Topographic and Geomorphological Characteristics}

Nemrut Mount National Park and its surroundings that situated between the Adiyaman-Kahta plateau and the Southeastern Taurus Mountains that were rised on these two main morphological structures have taken their present form as a result of young tectonic movements folding and fracturing of geomorphological units rather than paleotectonic movements. In the neotectonic (young tectonic movements) period, the mountainous areas corresponding to the anticlines were rised by cutting faults, a series of small synclines between their by merging basin floors were descended. Kahta Stream that is the most important water in the region was buried in the bed and formed deep gorges and valleys (Atalay et al. 2002; Sunkar and Karataş, 2014). 


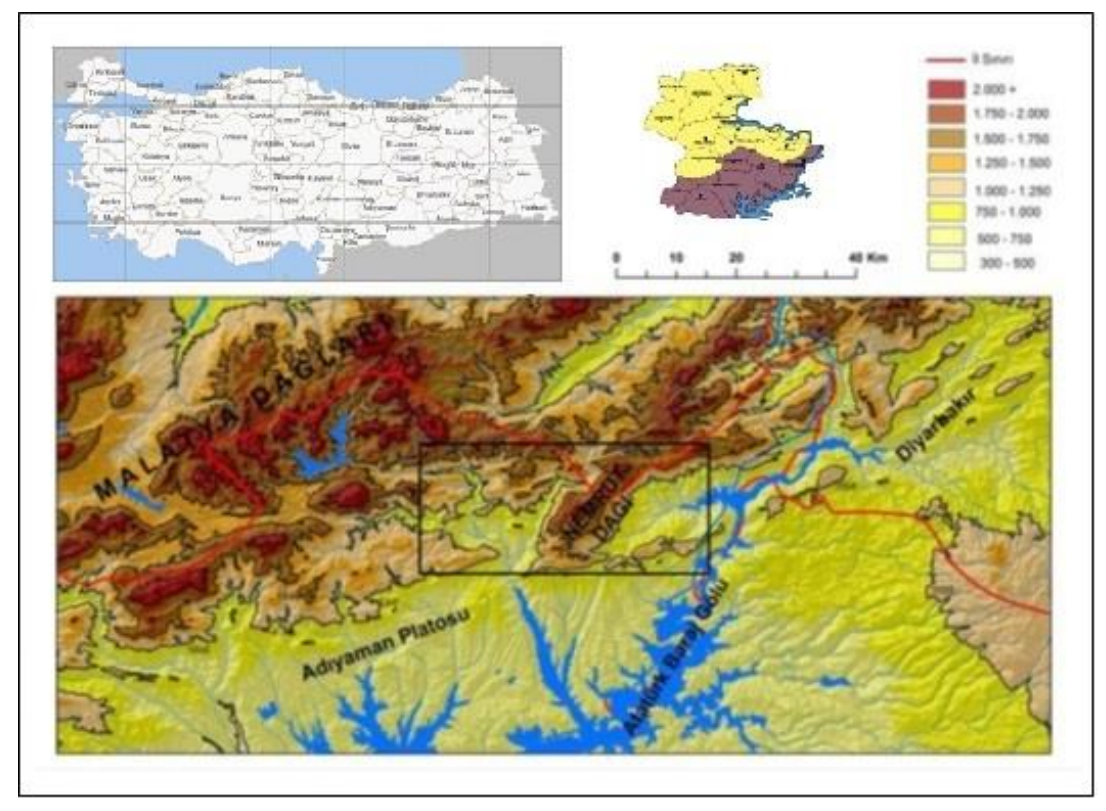

Figure 1. Locality of the study area (changed from Bozdağ, 2015).

The orographic structure of the region constitutes the highest part of the area which is mountainous areas extending in three series parallel to each other in the NE-SW direction, which Mount Nemrut (2206 m) is in the east of the valley Kâhta, Mount Halof (1400 m) is the west and Sincik Kekdan mountain (1121 $\mathrm{m})$ is the north. Kahta river valley floor $(550 \mathrm{~m})$ that divides the area into three parts constitutes the lowest part of the area (Figure 2).

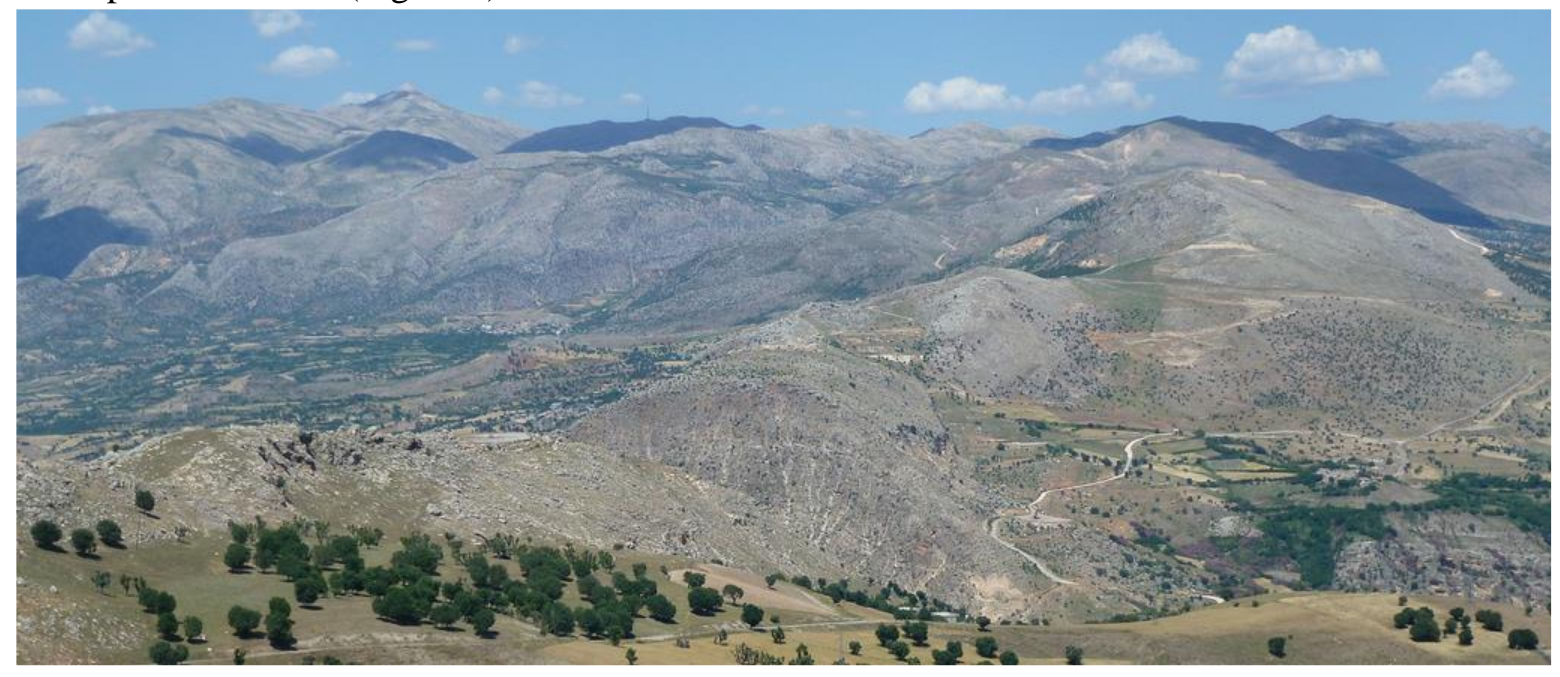

Figure 2. A view of Mount Nemrut National Park.

\section{Geological Characteristics}

The Nemrut Mountain National Park and its surroundings is to lie structurally between the transition zone in the Southeast Anatolian Miocene basin and in the Paleozoic metamorphic Bitlis massif in the north.

The geologic structure constitutes Mesozoic ophiolite series (peridotite, serpentine, limestone, radiolarite) and Lower Eocene clayey limestones is at the bottom and fractured Limestones lie over their. Şelmo formation, which represent Upper Miocene and settled correlator depots is on both sides of Kâhta stream and Plio-Quaternary fillings in the form of islets are on the Şelmo formation (Atalay et al., 2002, Karadogan, 2005). 


\section{Soil Properties}

In the study area, Brown Forest Soils on lime-rich bedrock are in south and north. Lime-free Brown Forest Soils that are the widest distribution are in the northwest, east and western ends. Brown Soils are in the east and south, Lime-free Brown Soils are on the summit of Mount Nemrut and in Belli plateaus and Reddish Brown Soils are around the bed of Kâhta Stream.

The Reddish Mediterranean Soils are generally observed in the karstic areas. Due to the characteristics of the karstic area the soil is not on the surface but between the cracks and the layers of the limestones in the sloped area. Vertisols are observed in the pits (dolin) in karstic areas. There are Red Soils with high physiological depths on and between the gravel deposits on the slopes of the steep facing the Kahta stream of the Nemrut Mountain and on some slopes.

There are mass of sand and gravel on the large floodplain formed by Kahta river and alluvial (Quaternary) rich soils in places where Gedik stream and Kâhta river and its branches are (Atalay et al., 2002).

\section{Climate Characteristics}

In the study area, the continental mountain climate, which is long winters with heavy snow and limited number of sunny days prevails in the highlands. The low slopes of the mountains facing south and around the Kahta stream are dominated by mild climate conditions which can be expressed as a distorted Mediterranean climate (Atalay et al., 2002).

Regarding the temperature regime, there is a 4-month summer season between June and September, and a winter season of approximately 4.5 months from mid-November to the end of March and spring and fall seasons with a duration of 1.5-2 months. According to the meteorological data of the districts close to the research area (Kahta and Pütürge), the average annual temperature is $12-17^{\circ} \mathrm{C}$, the average rainfall is $53-43 \mathrm{~mm}$, the average annual relative humidity varies between $47-52 \%$ (http://www.mgm.gov.tr ).

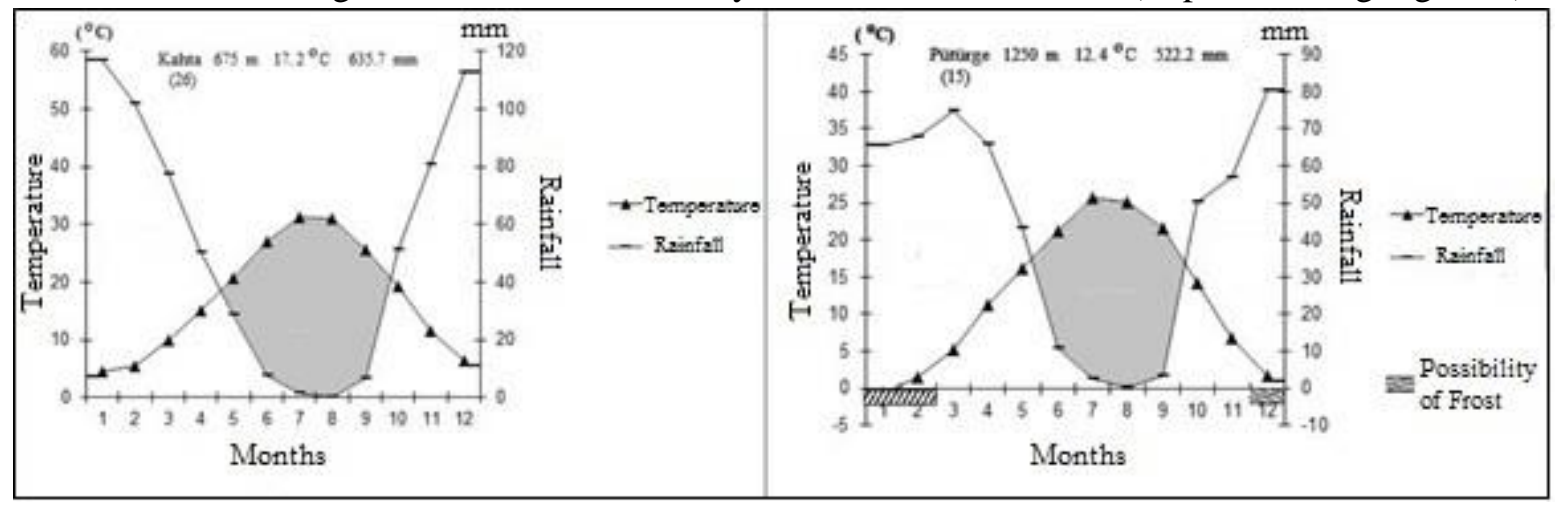

Figure 3: Kâhta and Pütürge districts climate diagram

\section{Hydrological characteristic}

The Kahta river and its branch which are an important river situated the northern and western and the Gedik stream (Kan stream) is in the southern and southeastern in the study area. The streams other than Kâhta river and Kan stream are generally temporary streams.

\section{Vegetation}

According to Davis (1971), the study area is located the C7 square in the Mesopotamian sub-region of the Iranian-Turanian floristic region characterized by a high proportion of dwarf shrubs, grasses and meadow although the tree species are relatively a small number (Davis, 1965-1985). According to Walter (1956), the zonal vegetation of the research area in this climate zone is "Step Humid Step Forest Zone", and Zohary's (1973) classification of plant regions is "Iranian xerophile Quercus brantii forest". 
These dry forests which generally consist of pure oak communities, are described as free-standing trees steppe which are the continuation of oak-juniper forests spreading on the slopes of the Western and Central Taurus Mountains and were spread on steppe's side (Louis, 1939, Mayer and Aksoy, 1998).

\section{Collection, preparation and identification of plant material}

The materials of this study are 2500 vascular plant specimens collected from Nemrut Mount National Park and its surroundings in different vegetation formation between 2010 and 2013. Efforts were made to collect both flowering and fruiting specimens. When the specimens were identified the color slides and photographs taken during the field studies were utilized. The specimens were prepared according to established herbarium techniques.

The Flora of Turkey (Davis, 1965-1985, Davis et al.,1988, Güner et al., 2000), were used for identification of the specimens. Specimens belonging to genera which were difficult to determine were sent to specialists to minimise errors. Apiaceae members were determined by Karakuş, Astragalus specimens were determined by Aytaç, Brasicaceae members were determined by Mutlu, Centaurea, Cyanus and Psephellus specimens were determined by Kaya, some Fabaceae members were determined by Akan, some Lamiceae members were determined by İlçim, Onosma specimens were determined by Binzet and some Poaceae and Asterceae members by Arabac1, Rosaceae members by Ok and some species were compared to the Herbarium of İnönü University (Malatya) (Figure 4).

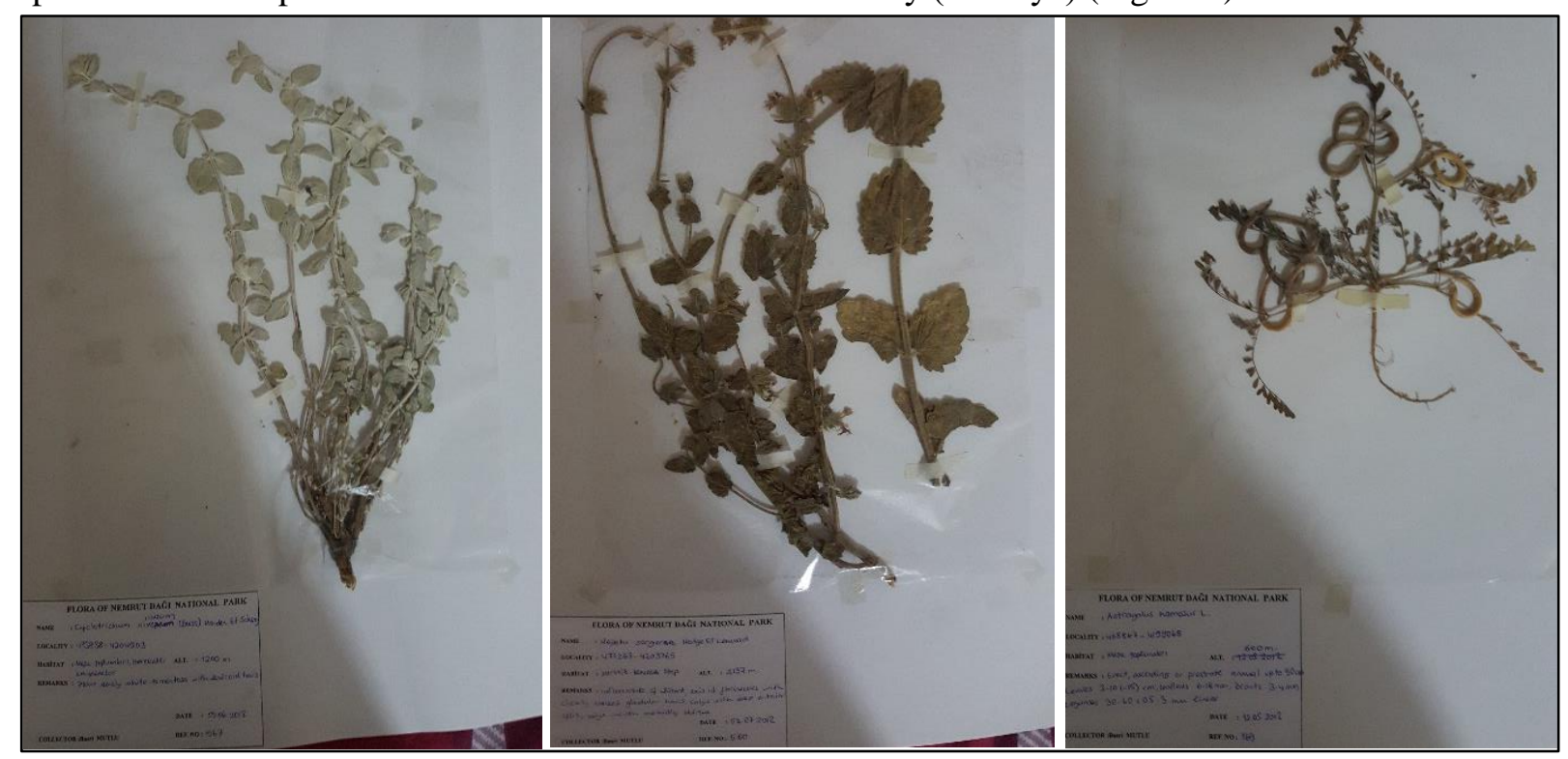

Şekil 4. Herbarium materials

The floristic lists were written in the same order as in the Flora of Turkey by checking on the IUCN website and the locality collected, habitat, altitude, coordinate, registration number, phytogeographic region, whether endemic and IUCN hazard categories (EN: Endangered / Endangered, VU: Vulnerable (NT: Near Threatened, LC: Least Concern). Authors of plant names are written according to authors of Plant Names (Brummitt et al., 1992).

Herbarium materials are partly stored in Istanbul University, Faculty of Forestry, Department of Landscape Architecture and partly stored in my personal archive.

\section{Results and Discussion}

At the end of the studies of the 2500 vascular plant specimens collected study area, 777 species 403 genera belonging to 88 families were established between in 2010-2013. Floristik list is given apendix 1. 
118 of these taxa are endemic to Turkey and the rate of endemism is $15.19 \%$. This ratio is quite high when compared to the studies conducted near the research area. Due to the fact that the research area is located on the Southeast Taurus Mountains and at the intersection of two phytogeographic regions and has the different climatic characteristics, soil structure, geographic status, geological and habitat characteristics.

8 (eight) species, Erysimum nemrutdaghense Mutlu, Heldreichia atalayi Kit \& Tan, Allium nemrutdaghensis Kit \& Tan, Nepeta sorgerae Hedge and Lamond, Nepeta aristata Boiss. \& Kotschy ex Boiss., Silene nemrutensis K.Yıldı, Minuartia tchihatchewii (Boiss.) Hand-Mazz., Gladiolus humilis Stapf are endemic to Mt. Nemrut and known only from the type localities. The first 8 species were collected for the second time from the type localities in the study area. However, some taxa recorded previously in study area could not collected from it, because of the narrowness of the distribution areas. These taxa are as follows: Astragalus commagenius (Kotschy \& Boiss.) Chamb., Arenaria antitaurica McNeill ve Taraxacum microcephaloides Soest.

According to the IUCN categories 7 species are in the EN (Endangered), 9 species are in the NT (Near threatened), 14 species are in the VU (Vulnerable) and 12 species are in the DD (Data Deficient) category (IUCN, 2019). Cicer bijugum Rech. fil. is a non-endemic but rare species. The taxa in the EN and VU categories are at high risk and require protection. Special attention should be given to the plants in the DD category since their status in nature cannot be clearly demonstrated (Ekim et al., 2000). The majority of taxa are in the LC (Lower Concerning) and LR (Lower Risk) category.

According to IUCN categories; Allium nemrutdaghense, Erysimum nemrutdaghense, Papaver arachnoideum Kadereit, Cicer bijugum, Johrenia dichotoma DC subsp. sintenisii Bornm., Gladiolus humilis Stapf, Blysmus compressus (L.) Panz. ex Link are in the EN (Endangered) category (IUCN, 2019).
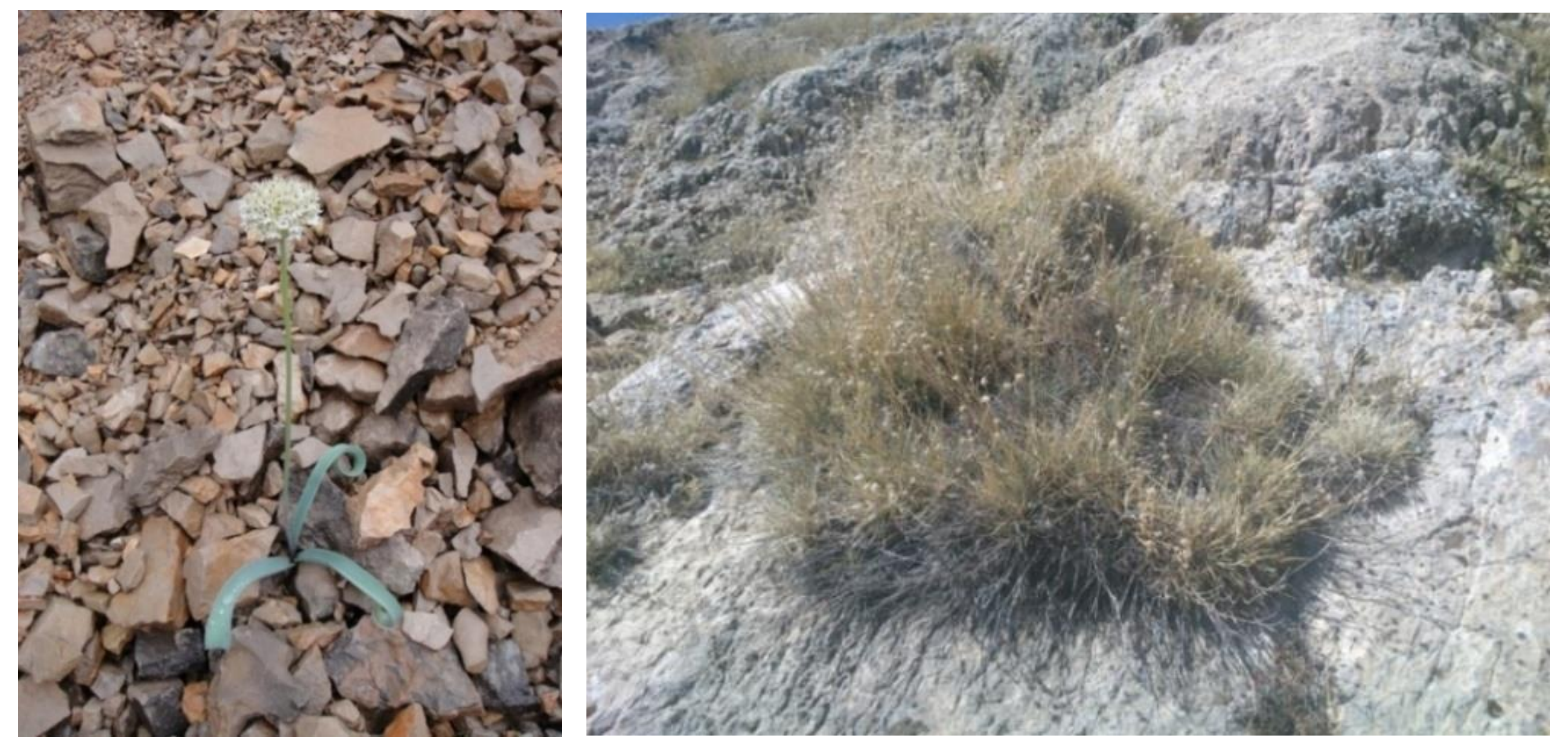

Figure 5: Endemic Allium nemrutdaghense on the left and Gypsophila pinifolia on the right 

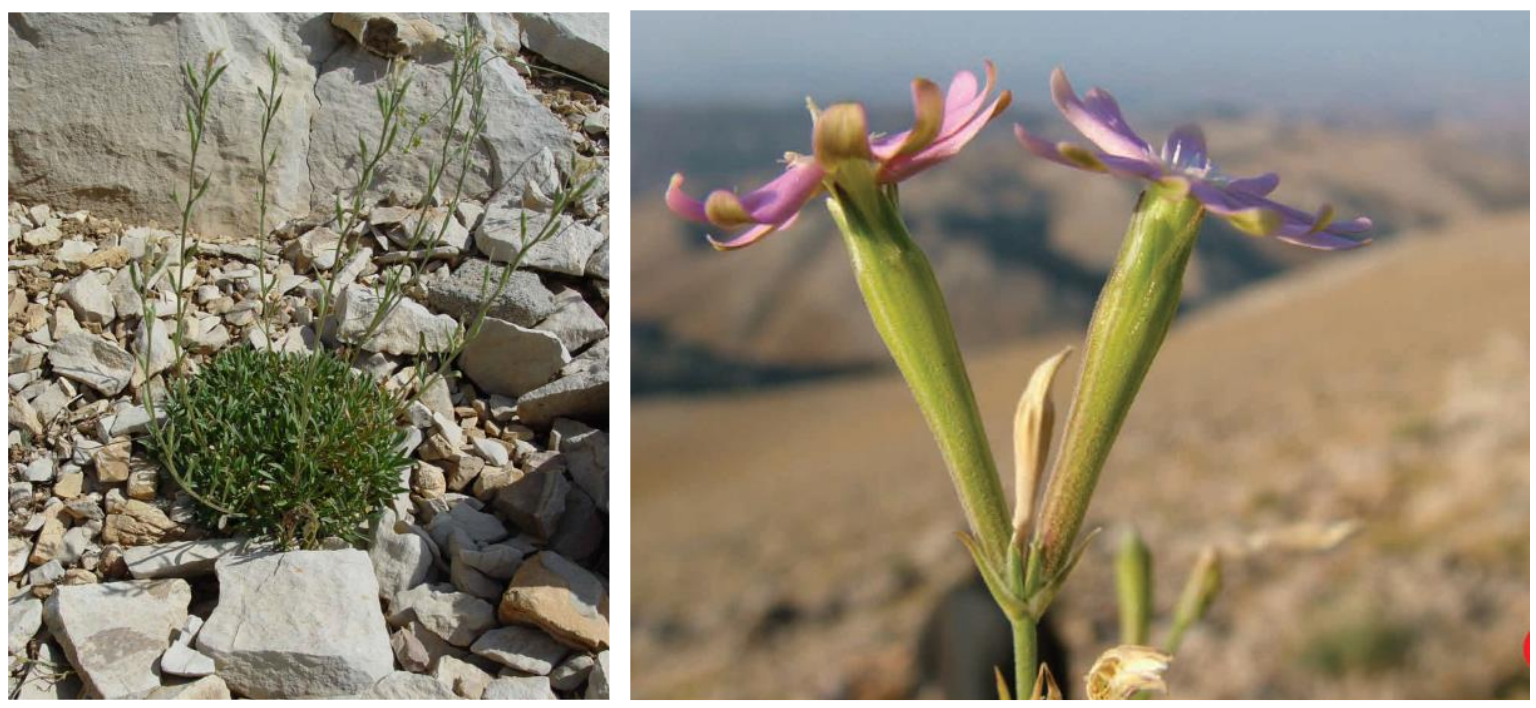

Figure 6: Endemic Erysimum nemrutdaghense on the left and Silene nemrutensis on the right

When it comes to distribution of known species of phytogeographical region in the study area, IranoTuranian elements comprise $271(34,9 \%)$ taxa, Mediterranean elements consist of $52(6,7 \%)$ taxa, E. Mediterranean elements are 44 (5,7\%), Euro-Siberian elements are $22(2,8 \%)$, and Euxin elements are only $2(0,3 \%)$ and the phytogeographic unknown are $386(49.7 \%)$.

Distribution number of taxa according to the phytogeographic are given in Table 1.

Table 1. Number of taxa according to the phytogeographic region

\begin{tabular}{ll}
\hline Number of taxa & The phytogeographic region \\
\hline 271 & Irano-Turanian \\
52 & Mediterranean \\
44 & East Mediterranean \\
22 & Euro-Siberian \\
2 & Euxin \\
386 & Unknown \\
\hline
\end{tabular}

In terms of number of taxa known the phytogeographic region, Irano-Turanian elements and Mediterranean (Mediterranean + East Mediterranean) elements rank first and second respectively on Mt. Nemrut National Park and its surroundings. Irano-Turanian elements are the highest because the study area locates the Iranian-Turanian floristic region and compose mainly of calcareous and steppic areas. Mediterranean elements are second, as the climate affecting on study area is not uniform and as well as on the Mediterranean Transition Biosome. Euro-Siberian elements that mostly adapted to meadow and wetland habitats are the small number, since the study area is distant to this phytogeographic region and has a dry climate.

The distribution of the majority of the taxa and the numbers of species which belong to these families in the research area are listed in Table 2.

Twenty families comprise 614 species of the 777 taxa established in the study area. In other words $79.2 \%$ of the flora of national park and its surounding consists of species that belong to 20 families. For these reasons, the species belonging to the 20 families listed in Table 2 are dominant in the steppic vegetation. The remaining 68 families, comprising 163 species, are represented by one or a few species in the area and constitute $20.98 \%$ of the flora of Nemrut Mountain National Park. 
Table 2: Families with the highest taxa

\begin{tabular}{lcclcc}
\hline Families & $\begin{array}{c}\text { Taxa } \\
\text { number }\end{array}$ & $\boldsymbol{\%}$ & Families & $\begin{array}{c}\text { Taxa } \\
\text { number }\end{array}$ & $\%$ \\
\hline ASTERACEAE & 96 & 12.3 & RANUNCULACEAE & 20 & 2.6 \\
FABACEAE & 85 & 10.9 & PLANTAGINACEAE & 19 & 2.4 \\
LAMIACEAE & 57 & 7.3 & EUPHORBIACEAE & 12 & 1.5 \\
BRASSICACEAE & 57 & 7.3 & PAPAVERACEAE & 11 & 1.4 \\
POACEAE & 51 & 6.6 & ASPARAGACEAE & 11 & 1.4 \\
CARYOPHYLLACEAE & 43 & 5.5 & POLYGONACEAE & 11 & 1.4 \\
APIACEAE & 40 & 5.2 & AMARYLLIDACEAE & 11 & 1.4 \\
ROSACEAE & 29 & 3.7 & HYPERICACEAE & 9 & 1.2 \\
BORAGINACEAE & 26 & 3.4 & CAMPANULACEAE & 8 & 1.0 \\
RUBIACEAE & 22 & 2.8 & ORCHIDACEAE & 7 & 0.9 \\
\hline
\end{tabular}

In terms of the number of taxa, Asteracea family and Fabaceae family rank first and second respectively as in Turkey's flora. The reason why the Asteraceae family is in the first row can be explained due to more tolerant to ecological factors, the ability to easily distribute the fruits and grow up mainly of calcareous and steppic areas. That the Fabaceae family is in the second row can be deduced that the research area provides a suitable ecological environment for the growth of these taxa. In terms of the number of genera and its families are listed in Table 3.

Table 3. Species totals of the major genera

\begin{tabular}{lclc}
\multicolumn{1}{c}{ Genera/Families } & $\begin{array}{c}\text { Species } \\
\text { Number }\end{array}$ & \multicolumn{1}{c}{ Genera/Families } & $\begin{array}{c}\text { Species } \\
\text { Number }\end{array}$ \\
\hline Astragalus (Fabaceae) & 20 & Centaurea (Asteraceae) & 10 \\
Silene (Caryophyllaceae) & 16 & Allium (Liliaceae) & 10 \\
Prunus (Rosaceae) & 13 & Ranunculus (Ranunculaceae) & 9 \\
Salvia (Lamiaceae & 11 & Hypericum (Hypericaceae) & 9 \\
Alyssum (Brassicaceae) & 11 & Trifolium (Fabaceae) & 8 \\
Medicago (Fabaceae) & 11 & Erysimum (Brasicaceae) & 8 \\
Galium (Rubiaceae) & 11 & Minuartia (Caryophyllaceae) & 7 \\
Vicia (Fabaceae) & 10 & Scorzonera (Asteraceae) & 7 \\
Veronica (Scrophulariaceae) & 10 & Papaver (Papaveraceae) & 7 \\
Euphorbia (Euphorbiaceae) & 10 & Aethionema (Brasicaceae) & 7 \\
\hline
\end{tabular}

As can be seen from Table 3, the Astragalus L. species are dominant in the study area. Because as stated previously, calcareous and steppic areas are common in the study area and Astragalus is a mainly steppic genus as well as one of the largest genera of flowering plants that has approximately 2500 species world wide. The estimated number of species in Turkey, which are mainly Irano-Turanian elements, is around 400. Likewise, Silene L., Prunus L., Salvia L., Alyssum L., Vicia L., Veronica L., Euphorbia L., Centaurea L. and Allium L. are mainly steppic genera and these comprise relatively more species. Trifolium L., Vicia and Euphorbia as well as Prunus are quite widespread in forest areas.

\section{Conclusion}

Nemrut Mountain National Park was declared a national park in 1989 for the protection of its historical and archaeological values. However, since the flora and vegetation structure of the national park area could not be revealed exactly, the biological diversity of the area has not been investigated sufficiently too. In this study, it is determined that the area is very rich in florstic and the rate of endemism is quite high. When the ratio of known species of phytogeographic region is examined, that the Iranian-Turanian element is high, since the area is located in this phytogeographic region. However, the presence of other elements in the region shows that the site has rich and varied habitats due to its geomorphological structure. 
The floristic inventory studies conducted showed that the study area has a rich biodiversity as well as archaeological values. Therefore it can be separated as a biosphere reserve with its relatively untouched natural features besides being a national park with its cultural features. In particularly, the areas where are karstic shaped, where have endemic plants, where are high mountain steppe, where are forest and where have archaeological remains are potential for biological reserv.

\section{References}

Atalay, İ., Günek, H. ve Karadoğan, S. (2002). Nemrut Dağı'nın Doğal Ortam Özellikleri ve Turizm Potansiyeli, Türkiye Dağları I. Sempozyumu, 25-27 Haziran Bolu.

Brummitt RK \& Powell CE (eds.) (1992). Authors of Plant Names. Kew: Royal Botanic Gardens.

Bozdağ, E. (2015). Nemrut Dağı (Adıyaman) ve Çevresinin Jeopark Olma Potansiyelinin Araştırılması, Yüksek Lisans Tezi, T.C. Harran Üniversitesi, Sosyal Bilimler Enstitüsü, Coğrafya Anabilim Dalı, Şanlıurfa.

Çakan, H., Düzenli, A., Türkmen, N., Yılmaz, K. T., Karaömerlioğlu, D. (2004). Nemrut Dağı’nın (Adıyaman) Endemik ve Nadir Bitki Türleri. XVII. Ulusal Biyoloji Kongresi 5. Seksiyon Sözlü, Poster ve Serbest Bildiri Özetleri 21-24 Haziran 2004, Çukurova Üniversitesi, Adana, s 51.

Davis, PH (ed.) (1965-1985). Flora of Turkey and the East Aegean Islands, vols. 1-9. Edinburgh: Edinburgh Univ Press.

Davis PH, Mill RR \& Tan Kit (eds.) (1988). Flora of Turkey and the East Aegean Islands (supplement), vol. 10. Edinburgh: Edinburgh Univ. Press.

Ekim, T., Koyuncu, M., Vural, M., Duman H., Aytaç, Z., Adıgüzel, N. (2000). Türkiye Bitkileri Kırmızı Kitabı. Ankara: Türkiye Tabiatını Koruma Derneği ve Van Yüzüncü Yıl Üniv Yay.

Güner A, Özhatay N, Ekim T \& Bafler KHC (eds.) (2000). Flora of Turkey and the East Aegean Islands (supplement), vol. 11. Edinburgh: Edinburgh Univ. Press.

IUCN, (2019). https://www.iucnredlist.org

Karadoğan, S., (2005). Adıyaman Havzasının Genel ve Uygulamalı Jeomorfolojisi, Doktora Tezi, Fırat Üniv. Sosyal Bilimler Enstitüsü, Elâzı̆g.

Louis, H. (1939). Das Natürliche Pflanzenkleid Anatoliens, Geographische Abhandlungen, 3. Reihe, Heft 12, Stuttgart.

Mayer, H. and Aksoy, H. (1998). Türkiye Ormanları (Walder der Türkei). Batı Karadeniz Ormancılık Araştırma Enstitüsü Müdürlüğü, Orman Bakanlı̆̆ı Yayın No. 038, Müdürlük Yayın No. 2, Muhtelif Yayın No. 1 Bolu (Çeviri: Hüseyin AKSOY, Gülen ÖZALP).

Mutlu, B., (2018). A new perennial Erysimum species from Turkey, E. Nemrutdaghense (Brassicaceae) Phytotaxa 336 (3) () 2018 Magnolia Press, ISSN 1179-3163 (online edition).

Tel, A. Z., (2001). Nemrut Dağı (Adıyaman) Vejetasyonu, Doktora Tezi, YYÜ Fen Bilimleri Enstitiüsü.

Yılmaz K. T., Düzenli, A., Çakan H.,̇̇zcankurtaran Y., (2005). Nemrut Dağı Ve Karatepe-Aslantaş Milli Parkları Örneğinde Bitki Örtüsüne Ait Verilerin Koruma Planlamasında Kullanımı, Korunan Alanlar Sempozyumu, S: 639-646, Isparta.

Uzun, G., ve diğ., (2001). Nemrut Dağı Milli Parkı Uzun Devreli Gelişme Planı Analitik Raporu. Ç.Ü. Ziraat Fakültesi Peyzaj Planlama Bölümü, Yayınlanmamış Taslak Rapor, Adana

Walter, H., (1956). Vegetationsgliederung Anatoliens. Flora oder Allg. Bot. Zeit., 143, 295-326.

Yıldız, K., Çırpıcı, A., Dadandı, MY and Fırat M., (2017). Silene nemrutensis (Caryophyllaceae), a new species from south-eastern Anatolia, Phytotaxa 292 (2): 189-195, (c) 2017 Magnolia Press, ISSN 1179-3163 (online edition).

Yıldız, B., Bahçecioğlu Z., Arabacı T. (2004). Floristic Characteristics of Beydağı (Malatya), Turk J Bot. 28 (2004) $391-419$ 
Zohary, M. (1973). Geobotanical Foundations of the Middle East. Volumes 1 \& 2. Gustav Fischer Verlag, Stuttgart \& Swets \& Zeitlinger, Amsterdam.

Submitted: 02.09.2019 Accepted:16.02.2020 